International Journal of Instruction e-ISSN: 1308-1470 • www.e-iji.net

Article submission code: 20200926225227

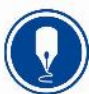

October $2021 \bullet$ Vol.14, No.4

p-ISSN: 1694-609X

pp. 439-450

Received: 26/09/2020

Revision: 24/03/2021
Accepted: 17/04/2021

OnlineFirst: 08/08/2021

\title{
Assessing Students' Attitudes towards Physics through the Application of Inquiry and Jigsaw Cooperative Learning Models in High Schools
}

\author{
Maison \\ Assoc. Prof., Jambi University, Indonesia, maison@unja.ac.id \\ Tanti \\ UIN Sultan Thaha Saifuddin Jambi, Indonesia, tanti@uinjambi.ac.id \\ Dwi Agus Kurniawan \\ Jambi University, Indonesia, dwiagus.k@unja.ac.id \\ Weni Sukarni \\ Jambi University, Indonesia, wenisukarni282.ws@gmail.com \\ Erika \\ Jambi University, Indonesia, erk.erikaaaaa@gmail.com \\ Roro Hoyi \\ Jambi University, Indonesia, rorohoyi3@gmail.com
}

\begin{abstract}
This research was conducted on students of two senior high schools in Jambi, Indonesia, where the two schools have almost the same characteristics but apply different cooperative learning models, namely the inquiry learning model and the Jigsaw learning model. The purpose of this study was to assess students' attitudes towards physics through the application of inquiry and Jigsaw cooperative learning models. The number of respondents for the inquiry model was 28 students and Jigsaw 27 students. This study used a mixed-method convergent parallel design to collect and analyze quantitative and qualitative data for each group. Quantitative data collection was carried out using the adopted instruments of students' attitudes towards physics, which consisted of 54 items under seven scales. Meanwhile, qualitative data were collected through interviews with eight students from both groups. The results show that students have positive attitudes towards physics, such as attitudes towards investigation in physics, enjoyment in learning physics, adoption of scientific attitudes, and increasing their time for study. Statistical results using the Mann-Whitney $U$ test showed no significant difference in attitudes in the two groups.
\end{abstract}

Keywords: inquiry learning, cooperative learning, jigsaw model, physics, learning models

Citation: Maison., Tanti., Kurniawan, D. A., Sukarni, W., Erika., \& Hoyi, R. (2021). Assessing students' attitudes towards physics through the application of inquiry and jigsaw cooperative learning models in high schools. International Journal of Instruction, 14(4), 439-450. https://doi.org/10.29333/iji.2021.14426a 


\section{INTRODUCTION}

Physics is a natural science subject that is admittedly difficult to learn and teach (Mulhall \& Gunstone, 2012). The characteristics of physics, which mostly consist of abstract concepts with complex mathematical calculations, make physics devoid of enthusiasts (Duit, Schecker, Dietmar, \& Nieddere, 2014). Most high school students consider physics a difficult subject than other branches of science such as biology and chemistry, which worsens when they enter college. As a result, high school students' interest in studying physics has decreased significantly every year (DeWitt, Archer, \& Moote, 2019; Osborne, Simon, \& Collins, 2010). Various educational research shows that students consider physics suitable only to be learned by gifted, smart, and master mathematics students (Guido, 2013).

Research conducted by DeWitt et al. (2019) showed students' belief in the characteristics of physics knowledge (ex. rugged, masculine, etc.) made students have a negative attitude that physics is "not for me" and finally choose another route. In Asia, studies conducted by Oon and Subramaniam (2013) show mixed results. According to Oon \& Subramaniam (2013), most Singapore students are interested in studying physics and realize that physics plays a vital role in supporting career and technological development. Even so, the image that physics is complicated remains the primary reason why some students in Singapore do not take physics in their advanced studies (Oon \& Subramaniam, 2013). Meanwhile, Susongko and Fatkhurrahman (2017) stated that the achievement of Indonesian students in physics on the Trend in International Mathematics Science Studied (TIMSS) was directly influenced by self-efficacy, interest, and students' attitudes towards physics.

The consensus among education researchers agrees on the importance of affective aspects in learning: student attitudes. As stated by Guido (2013), attitude determines how a person processes incoming information. Furthermore, Guido (2013) explains that negative attitudes can distort perceptions and affect information retention. In the context of learning physics, students' attitudes describe evaluative reactions expressed by feeling like or dislike the material being studied. Students who have a positive attitude tend to have high motivation, respect teachers, actively learn, and have good physics problemsolving skills (Guido, 2013). In contrast, students with negative attitudes not only dislike physics material; they also dislike teachers, are passive in learning, and have low learning achievement. Some researchers (For example, Maison, Syahrial, Syamsurizal, \& Tanti, 2019; Tanti et al., 2018; Wang, Guo, \& Jou, 2015) highlighted that the learning environment plays a role, especially in how teachers encourage students to learn, in building students' beliefs and attitudes towards physics.

Inquiry and jigsaw cooperative learning models direct students to learn "how to learn" (Hänze \& Berger, 2007). These models have learning characteristics that emphasize student activeness by linking new information to students' initial knowledge and a collaborative and cooperative learning process (Hänze \& Berger, 2007; Wang et al., 2015). Since these two models are student-centered, prioritizing critical thinking skills, problem-solving, decision-making, questioning skills, inquiry, and jigsaw learning models encourage students to develop the skills they need in this 21 st century (Wang et 
al., 2015). Students learn facts or problem-solving procedures in physics and have ideas and conceptual understanding to explain the factual situations they observe as a scientist works (Wang et al., 2015).

The use of these two learning models has a long history in science learning. As Hänze \& Berger (2007) and Bogar (2019) stated, these two models are based on a constructivist paradigm in which students are the primary agents responsible for the knowledge construction process. Research shows that these two models have been successful in encouraging student achievement (Byers, Imms, \& Hartnell-Young, 2018), problemsolving ability (Gök \& Sýlay, 2010), and student conceptual understanding in physics (Lazonder \& Harmsen, 2016). However, research on inquiry and jigsaw models on students' attitudes towards physics is still very limited, especially in Indonesia. Therefore, this study aims to analyze the effect of using the cooperative model of inquiry and Jigsaw on students' attitudes in studying physics. This study will contribute to using collaborative learning models in physics and recommend practical things to teachers about how physics learning should be packaged excitingly and accommodate various student characteristics.

\section{METHOD}

This study used a mixed-method convergent parallel design to collect and analyze quantitative and qualitative data for each class. The mixed-method convergent parallel design (also referred to as the convergent design) is a one-phase design (Creswell \& Clark, 2011). Researchers apply quantitative and qualitative methods simultaneously and with the same weight to thoroughly understand a topic. The primary data sources were students from two high schools, SMA 3 and SMA 8, in Jambi, Indonesia. SMA 3 students are taught using the Jigsaw learning model, and SMA 8 students are taught using the inquiry model in physics teaching. Researchers used a random cluster sampling technique to determine one class in each school as research respondents. The number of respondents in SMA 3 (Jigsaw) was 27 students, and in SMA 8 (inquiry), 28 students.

There are several reasons why the two schools did not use the same model or why the two models were not applied to all respondents in the research. First, this research is a descriptive study, where the researchers only measure students' attitudes towards physics, and in fact, the teachers in both schools have applied these different models. Second, this technique makes it possible to determine how students' attitudes towards physics for the same physics material. Furthermore, the two schools have similar characteristics in terms of resources, facilities, and learning environment. So that differences caused by other factors can be minimized.

Quantitative data were collected using a questionnaire of students' attitudes towards physics (Darmawangsa, Atalini, \& Kurniawan, 2018), consisting of 54 items with a fivepoint Likert scale. This questionnaire has seven scales or indicators and a Cronbach Alpha of 0.9. Qualitative data were collected through observation during the learning process to record both descriptive and reflective field notes during the observation and interviews after using the Jigsaw and inquiry model. The number of students interviewed was four people for each group coded as IGS-1 to IGS-4 and JGS-1 to JGS-4. The 
selection of respondents to be interviewed was determined based on the purposive sampling technique; for example, the students selected were those who were willing to be interviewed.

Following the research design used, researchers analyze quantitative and qualitative data separately. Quantitative data were analyzed using SPSS software for descriptive analysis, such as central tendency and variability (Creswell, 2012). Likert scale interpretation used is 4.21-5.00 "strongly agree"; 3.41-4.20 "agree"; 2.61-3.40 "partially agree"; 1.81-2.60 "disagree"; and 1.00-1.80 "strongly disagree" (Eshetu, 2020). Then proceed with non-parametric inferential statistics to see differences in students' attitudes towards physics after learning using the inquiry model and Jigsaw model. Qualitative data were analyzed using generally accepted qualitative analysis techniques. The processes carried out include transcription of data into text and coding, which is useful for getting descriptions and themes. After the two types of data have been analyzed, quantitative and qualitative results are presented to describe students' attitudes towards physics.

\section{FINDINGS}

\section{Quantitative Findings}

The quantitative results of this study describe in several findings, namely the percentage of students' attitudes towards physics through inquiry learning (Table 1) and Jigsaw learning (Table 2), the mean tendency on each scale (Table 3), and the comparisons of attitudes in the two groups of students (Table 4).

Table 1

Percentage of students' attitudes towards physics through the application of the inquiry learning model

\begin{tabular}{lllll}
\hline Variable & Interval & Frequency & Percentage $(\%)$ & Category \\
\hline & $54.0-97.2$ & 0 & 0 & Very bad \\
Inquiry Learning & $97.3-140.4$ & 2 & $7.1 \%$ & Bad \\
Model & $140.5-183.6$ & 16 & $57.1 \%$ & Quite good \\
& $183.7-226.8$ & 10 & $35.7 \%$ & Good \\
& $226.9-270.0$ & 0 & 0 & Very good \\
\hline
\end{tabular}

Students' attitudes towards physics (Table 1) using the inquiry learning model were that two out of 28 students were categorized as having bad attitudes with a percentage of $7.1 \%$; There were 16 out of 28 students classified as good enough with a percentage of $57.1 \%$, and 10 out of 28 students in a good category with a percentage of $35.7 \%$.

Table 2

Percentage of students' attitudes towards physics through the application of the Jigsaw learning model

\begin{tabular}{lllll}
\hline Variable & Interval & Frequency & Percentage (\%) & Category \\
\hline & $54.0-97.2$ & 0 & 0 & Very bad \\
Jigsaw Learning & $97.3-140.4$ & 0 & 0 & Not good \\
Model & $140.5-183.6$ & 19 & 70.4 & Quite good \\
& $183.7-226.8$ & 8 & 29.6 & Good \\
& $226.9-270.0$ & 0 & 0 & Very good \\
\hline
\end{tabular}


Students' attitudes towards physics (Table 2) using the Jigsaw learning model were that 19 out of 27 students were categorized as having quite good attitudes with a percentage of $70.4 \%$. Eight out of 27 students were classified as having good attitudes, with a percentage of $29.6 \%$.

Table 3

Mean tendency for each scale of attitudes

\begin{tabular}{lllll}
\hline & Inquiry & \multicolumn{3}{c}{ Jigsaw } \\
\cline { 2 - 5 } & Mean & SD & Mean & SD \\
\hline Scale 1: Social Implications of Physics & 3.45 & 0.62 & 3.30 & 0.48 \\
\hline Scale 2: Scientist Normality & 3.31 & 0.35 & 3.38 & 0.53 \\
\hline Scale 3: Attitude towards Investigations in Physics & 3.07 & 0.40 & 3.26 & 0.41 \\
\hline Scale 4: Adoption of a Scientific Attitude & 3.48 & 0.47 & 3.68 & 0.64 \\
\hline Scale 5: Enjoyment in Learning Physics & 3.13 & 0.77 & 3.23 & 0.31 \\
\hline Scale 6: The Interest in Increasing Physics Study Time & 3.04 & 0.68 & 2.97 & 0.38 \\
\hline Scale 7: Career Interest in Physics & 3.18 & 0.53 & 3.33 & 0.34 \\
\hline
\end{tabular}

Table 3 shows that the two groups rated their attitudes towards physics on scientist normality, attitudes toward investigations in physics, enjoyment of studying physics, interest in increasing time to study physics, and interest in a career in physics as "partly agree". Meanwhile, on the adoption of a scientific attitude as "agree". However, there are differences in physics's social implications, where the inquiry group "agrees" and the Jigsaw group "partly agrees". Therefore the majority of respondents perceive their attitude to be quite good.

The results of non-parametric statistical tests using the Mann-Whitney U test are shown in Table 4.

Table 4

Test statistic of $\mathrm{U}, \mathrm{z}$, and $\mathrm{p}$

\begin{tabular}{llll}
\hline Statistic & Mann-Whitney U & Z & Asymp. Sig. (2-tailed) \\
\hline Total attitude & 376 & -0.034 & 0.973 \\
\hline
\end{tabular}

The value that is important to pay attention to in the Mann-Whitney U Test results is the $\mathrm{Z}$ value and the significant level. In this study, the $\mathrm{Z}$ value is -0.03 (rounded) with a significant level of $p=0.97$. The probability value ( $p$ ) is not less than or equal to 0.05 , so the comparison result is not significant.

\section{Qualitative Findings}

Students have good attitudes towards physics, shown by interviews with groups using the inquiry learning model and Jigsaw. Inquiry group students (IGS) and Jigsaw group students (JGS) said they enjoyed learning physics.

I like learning physics because the teacher explains the material more cheerfully. Also, studying Physics has many benefits for me, as I can know its application; of course, we often encounter it in daily life, but sometimes I wouldn't say I like it when the material is difficult to understand, and there are a lot of formulas (IGS-1)

I like learning physics if the material is easy to understand, and learning with friends is not alone (JGS-1) 
Students also like to learn through experiments because they are more active in learning, are not bored, and develop scientific skills.

I like experimentation because it makes me more skilled, critical, and more understanding. Besides, through the experiment, I can prove that a concept is real (IGS-2)

I like doing experiments because by doing experiments, I can observe and be active in learning. It is not dull and linked to everyday life (JGS-2)

Each student group's views on using the inquiry and Jigsaw learning model were also outstanding; this was revealed from their answers when interviewed. Students also want to increase their time studying physics

It is interesting because learning to use the inquiry learning model makes my curiosity about physical concepts and their applications, improves science skills, and conducts scientific problems through experiments to find concepts and conclude (IGS-3)

I like learning to use a Jigsaw, cooperative learning model. Because when applying this type of learning model, I can discuss and exchange opinions with other friends (IJS-3)

I want to increase my time in learning physics; I will study and discuss with friends to solve problems and find the concepts of the material being studied (JGS-4)

Based on the interview results, students feel interested in learning physics by using the inquiry learning model to improve scientific attitudes and student activeness by having experiments. Also, it makes students motivated to study physics seriously. Students can connect the material learned with the surrounding phenomena through this model because physics is often encountered in everyday life. So that learning physics is more meaningful for students.

Students try to solve problems and find physics concepts in learning through experiments and discussions with their peers. Applying the Jigsaw cooperative learning model can improve problem-solving abilities and students' concept discovery. Also, students feel interested in doing experiments to solve problems and find concepts.

\section{DISCUSSION}

In teaching and learning, the teacher has a role in helping students solve problems to achieve instruction goals. The application of the competency-based teaching system approach leads to individual management. It places students as subjects who must plan, explore, interpret, and evaluate their learning outcomes. Simultaneously, as a facilitator, the teacher must always be ready to serve students' learning needs. One of the teachers' efforts is to apply an appropriate learning model, for example, by implementing Jigsaw as a cooperative learning model. In the Jigsaw learning model, students are divided into heterogeneous groups. According to Wartono, Alfroni, Batlolona, \& Mahapoonyanont (2019), students will be divided into small groups with different ability levels. The teacher carries out the students' group formation based on specific considerations, such as academics ability, activeness, and gender of students. Students must cooperate with other students and work together and have the opportunity to process information and 
improve communication skills (Sulastri \& Rochintaniawati, 2009). Good interaction between teachers and students is needed in the teaching and learning process.

Another recommended learning model is the inquiry learning model since it offers student-centered, improves students' innovation skills in thinking and solving problems. Inquiry learning requires students to work collaboratively to ask questions, make temporary hypotheses, design an investigation, develop results and findings following obtained, and build communication (Wartono et al., 2019). The inquiry learning model is a learning model in which the student formulates the problem, designing experiments, collecting data, analyzing data, and making decisions all by themselves and must meet four criteria: clarity, appropriateness, accuracy, and complexity. Inquiry learning with science context is learning developed by using science to build and improve students' critical thinking skills (Pursitasari, Suhardi, Putra, \& Rachman, 2020; Sutiani, Situmorang, \& Silalahi, 2021).

The application of inquiry-based learning should also have pedagogical implications and provide a more engaging learning environment. However, students from inquiry-based learning laboratories experienced a sense of complexity and frustration in their practice. They completed their scientific experiments and procedures without the involvement of teachers. Besides, it must reconsider the role of triangulation relationships between the development of learners' knowledge, learning models, and teachers' role in the classroom to support learners' trust in their results according to their practice (Khalaf \& Zin, 2018). Inquiry learning activities maximally involve all student competencies to search for and investigate something (objects, phenomena, or events) creatively, critically, systematically, logically, and analytically. Through these activities, they can formulate their findings with confidence. In guided inquiry-based learning, the teacher has a role in determining the problem and the stages of the solution, and students solve the problem in a group discussion and draw conclusions independently. So that guided inquiry can be interpreted as one of the inquiry/discovery-based learning models that present the problem and the teacher's solution.

Jigsaw-type cooperative learning begins with forming small groups with the number of members by the number of expert sheets. The division of groups is based on diverse abilities, origins, and backgrounds. This group is called the original group, and each group member will get a different expert sheet. The expert sheet contains questions that aim to improve students' problem-solving abilities. The next step is for students who get the same expert sheet from each origin group will form an expert group. In expert groups, students discuss solving problems on the expert sheet. After the expert group discussion is finished, students return to the original group and present the discussion results from the expert group. Students also make questions and answers about the questions earlier (Hertiavi, Langlang, \& Khanafiyah, 2010).

In this type of Jigsaw, learning can be more meaningful by activating the schema or background of the student's experience. In addition, students work with their friends in a cooperative environment and have many opportunities to manage information, improve communication skills, and establish comprehensive interactions. Each group member is responsible for mastering the learning material section and teaching the material to other 
group members. The jigsaw model can help students be actively involved in learning in the classroom, increase student activity, and creativity in learning the subject matter. It also increases collaboration between students in study groups, improves the ability to express opinions related to the material being taught, and improves the ability to explain the knowledge or information back obtained (Saepudin, 2019).

This approach places students to actively shape knowledge, not just passively accept from the teacher. So knowledge is not just transferred by the teacher but must be built and raised by students to interact with existing information. The jigsaw model that distinguishes it from other cooperative learning models is dividing material into several parts. Each group member becomes an expert in one part of the material, then is responsible for teaching other members in one group through discussion activities. Before, the expert group must hold a meeting to discuss the assigned material section and prepare a summary of the presentation to be taught to their respective small groups. In addition to being responsible for each score, each student is also responsible for the team's score. The assessment can be adjusted to the activities carried out, such as group discussions. Evaluation of the discussion focused on aspects of participation, contribution, mutual respect, and confidence during the discussion. The assessment is carried out on all four parts to see involvement in group discussions, which is carried out following the syntax of Jigsaw type cooperative learning.

Inquiry learning is to uses an inductive approach in finding knowledge and centering on student activity. Students construct knowledge in inquiry learning and learn through active involvement with concepts and principles. Students with high curiosity, critical, evaluating their performance, and understanding new concepts without difficulty have a scientific attitude. These attitudes can help students learn scientifically, structured, and independently. Students are faced with problematic situations so that they are sensitive to problems. Students can generate their sensitivity to problems if they encounter situations that require a solution. Teachers should encourage students to look at problems, formulate them, and solve them to the extent of students' abilities.

Teachers can implement inquiry-based learning to overcome or reduce the problem of misunderstanding about physics. Inquiry-based learning gives students hands-on experience. The inquiry-based learning model views students as active thinkers who understand interactions with the environment, phenomena, and other individuals. Inquiry-based learning invites students to investigate and analyze experimental results and train students to solve problems based on data (Yuliati, Riantoni, \& Mufti, 2018). Students who participate in inquiry-based learning can use problem-solving skills actively, associate knowledge gained through their everyday experiences, and develop attitudes and skills to deal with this knowledge. It is essential for science teaching and learning to develop these attitudes and skills (Yakar \& Baykara, 2014).

Inquiry-based learning develops student-centered activities so that students use scientific research methods to achieve learning targets progressively. However, the inquiry process is always influenced by previous experiences, habits, and modes of thinking beforehand. It requires learning to follow the pattern of individual development. Therefore, we consider several activities when designing the investigative process. It 
allows students to use their strengths and find places of interest. Besides, students can complete the structure of knowledge among group members based on various activities. In a certain sense, the perception of student effectiveness is related to their learning motivation (Xie, Zhang, \& Wu, 2017). In connection with the researcher's observations, it is believed that the active participation of students in lessons by taking part in all activities and answering questions raised by teachers in and between-group discussions positively contributes to developing their critical thinking levels. Discussion increases participants' critical thinking level, helps students improve their ability to make connections between claims and evidence, and improves necessary thinking skills (Duran \& Dökme, 2016).

Student behavior at the stage of the inquiry learning model includes observing demonstrations, paying attention to questions, answering questions, listening to explanations. Next, follow the teacher's directions and sit according to the group, work on the worksheets, discuss with groups in simulating, discuss and work on worksheets with group members according to the time determined by the teacher. Students follow the teacher's directions to do a simulation, follow the teacher's advice to do LKS based on the simulation. One group presents the results of the group discussion, while the other group responds to the results of the advanced group discussion. Furthermore, students make conclusions with the teacher. Inquiry is a series of student learning activities that emphasize critical and analytical thinking processes to answer their problems.

Students identify the investigation variables (experiments) related to the problem. Then the students predict and propose hypotheses associated with the related variables. Students conduct group discussions to plan experiments to investigate the relationship between these variables. Designing an experiment requires students to formulate various alternative solutions to problem-solving (Asyhari \& Putri, 2017). The inquiry learning model requires students to have good communication abilities and work together in groups. In addition to learning, inquiry can increase students' insights and improve the ability to find concepts from their experiments (Pramudyawan, Doyan, \& 'Ardhuha, 2019).

This situation describes that the teacher offers positive aspects of the inquiry learning model, tending towards affective and procedural rather than articulating cognitive aspects or positive explanations. They recognize how practical activities and manipulations increase student motivation, involvement, and understanding (RomeroAriza, Quesada, Abril, Sorensen, \& Oliver, 2019).

\section{CONCLUSION}

Based on the results of research and discussion in this study, it can be concluded that the use of inquiry learning models in physics learning can increase student activity, independence, concentration and improve students' scientific skills to find a concept with an experiment. It can be proven by analyzing students' steps when experimenting, and student attitudes are more likely to be positive when learning is categorized quite well. Likewise, using a cooperative Jigsaw model can increase student activity, concentration, cooperation, and student responsibility in groups. Through cooperative 
learning models - inquiry and Jigsaw, students feel responsible for formulating, analyzing, solving problems, finding concepts, and presenting the discussions in front of the class. Learning physics is more meaningful for students, easy to remember the material, and more conducive. Students have positive attitudes towards physics, such as attitudes towards investigation in physics, enjoyment in learning physics, adoption of scientific attitudes, and increasing their time for study.

\section{ACKNOWLEDGMENT}

This article results from research supported by the University of Jambi, especially the Faculty of Teacher Training and Education through a research scheme.

\section{REFERENCES}

Asyhari, A., \& Putri, G. (2017). Pengaruh pembelajaran levels of inquiry terhadap kemampuan literasi sains siswa (The effect of learning levels of inquiry on students' scientific literacy skills). Scientae Educatia: Jurnal Pendidikan Sains, 6(2), 87-101.

Bogar, Y. (2019). Literature review on inquiry-based learning in science education. International Journal of Science and Education, 1(2), 91-118. Retrieved from https://academic.microsoft.com/paper/2946125952

Byers, T., Imms, W., \& Hartnell-Young, E. (2018). Comparative analysis of the impact of traditional versus innovative learning environment on student attitudes and learning outcomes. Studies in Educational Evaluation, 58(October 2017), 167-177. https://doi.org/10.1016/j.stueduc.2018.07.003

Creswell, J. W. (2012). Educational Research: Planning, conducting, and evaluating quantitative and qualitative research. In P. A. Smith (Ed.), Pearson (4th ed.). 501 Boylston Street, Boston: Pearson Education.

Creswell, J. W., \& Clark, V. L. P. (2011). Designing and conducting mixed methods research (2nd ed.). SAGE Publication.

Darmawangsa, R., Atalini, \& Kurniawan, D. A. (2018). Pengembangan instrumen sikap siswa sekolah menengah atas mata pelajaran fisika (Development of attitude instruments for high school students on physics subjects). Jurnal Pendidikan Fisika Universitas Muhammadiyah Makassar, 6(1), 107-114.

DeWitt, J., Archer, L., \& Moote, J. (2019). 15/16-year-old students' reasons for choosing and not choosing physics at a Level. International Journal of Science and Mathematics Education, 17(6), 1071-1087. https://doi.org/10.1007/s10763-018-9900-4

Duit, R., Schecker, H., Dietmar, H., \& Nieddere, H. (2014). Teaching physics. In Handbook of research on science education (II, pp. 434-456).

Duran, M., \& Dökme, İ. (2016). The effect of the inquiry-based learning approach on student's critical thinking skills. EURASIA Journal of Mathematics, Science and Technology Education, 12(12). https://doi.org/10.12973/eurasia.2016.02311a

Eshetu, M. (2020). Identifying improvements in supervision practices in Ethiopian primary schools: A pragmatic perspective. Issues in Educational Research, 30(3), 866-882. 
Gök, T., \& Sýlay, I. (2010). The effects of problem solving strategies on students' achievement, attitude and motivation. Latin-American Journal of Physics Education, 4(1), 7-21.

Guido, R. M. D. (2013). Attitude and motivation towards learning physics. International Journal of Engineering Research \& Technology, 2(11), 2087-2094.

Hänze, M., \& Berger, R. (2007). Cooperative learning, motivational effects, and student characteristics: An experimental study comparing cooperative learning and direct instruction in 12th grade physics classes. Learning and Instruction, 17(1), 29-41. https://doi.org/10.1016/j.learninstruc.2006.11.004

Hertiavi, M. A., Langlang, H., \& Khanafiyah, S. (2010). Penerapan model pembelajaran kooperatif tipe Jigsaw untuk peningkatan kemampuan pemecahan masalah siswa SMP. $\begin{array}{llll}\text { Jurnal Pendidikan Fisika Indonesia, } & 6(1), & 53-57 .\end{array}$ https://doi.org/10.15294/jpfi.v6i1.1104

Khalaf, B. K., \& Zin, Z. B. M. (2018). Traditional and inquiry-based learning pedagogy: A systematic critical review. International Journal of Instruction, 11(4), 545-564. https://doi.org/10.12973/iji.2018.11434a

Lazonder, A. W., \& Harmsen, R. (2016). Meta-analysis of inquiry-based learning: Effects of guidance. Review of Educational Research, 86(3), 681-718. https://doi.org/10.3102/0034654315627366

Maison, Syahrial, Syamsurizal, \& Tanti. (2019). Learning environment, students' beliefs, and self-regulation in learning physics: Structural equation modeling. Journal of Baltic Science Education, 18(3), 389-403. https://doi.org/10.33225/jbse/19.18.389

Mulhall, P., \& Gunstone, R. (2012). Views about learning physics held by physics teachers with differing approaches to teaching physics. Journal of Science Teacher Education, 23(5), 429-449. https://doi.org/10.1007/s10972-012-9291-2

Oon, P.-T., \& Subramaniam, R. (2013). Factors influencing Singapore students' choice of physics as a tertiary field of study: A Rasch analysis. International Journal of Science Education, 35(1), 86-118. https://doi.org/10.1080/09500693.2012.718098

Osborne, J., Simon, S., \& Collins, S. (2010). Attitudes towards science: A review of the literature and its implications. International Journal of Science Education, 25(9), 10491079. https://doi.org/10.1080/0950069032000032199

Pramudyawan, M. T. S., Doyan, A., \& 'Ardhuha, J. (2019). Effect of guided inquiry learning model assisted by work and energy experiment tool kit on mastery of physics concepts student. Jurnal Penelitian Pendidikan IPA, 6(1), 40. https://doi.org/10.29303/jppipa.v6i1.290

Pursitasari, I. D., Suhardi, E., Putra, A. P., \& Rachman, I. (2020). Enhancement of student's critical thinking skill through science context-based inquiry learning. Jurnal Pendidikan IPA Indonesia, 9(1), 97-105. https://doi.org/10.15294/jpii.v9i1.21884

Romero-Ariza, M., Quesada, A., Abril, A. M., Sorensen, P., \& Oliver, M. C. (2019). Highly recommended and poorly used: English and Spanish science teachers' views of 
inquiry-based learning (IBL) and its enactment. EURASIA Journal of Mathematics, Science and Technology Education, 16(1), 1-16. https://doi.org/10.29333/ejmste/109658

Saepudin, A. (2019). Analisis keterampilan menjelaskan dan kemampuan pemecahan masalah pada konsep ekosistem melalui implementasi model Jigsaw (Analysis of explaining skills and problem solving abilities in ecosystem concepts through the implementation of the Jigsaw model). Jurnal Edukasi Matematika Dan Sains, 6(1), 30. https://doi.org/10.25273/jems.v6i1.5319

Sulastri, Y., \& Rochintaniawati, D. (2009). Pengaruh penggunaan pembelajaran kooperatif tipe Jigsaw dalam pembelajaran biologi di SMPN 2 Cimalaka (The effect of using Jigsaw cooperative learning in biology learning at SMPN 2 Cimalaka). Jurnal Pengajaran Matematika Dan Ilmu Pengetahuan Alam, 13(1), 15. https://doi.org/10.18269/jpmipa.v13i1.302

Susongko, P., \& Fatkhurrahman, M. A. (2017). Determinants factors analysis of Indonesian students' physics achievement in TIMSS 2011. Jurnal Pendidikan Fisika Indonesia, 13(1), 49-58. https://doi.org/10.15294/jpfi.v13i1.8641

Sutiani, A., Situmorang, M., \& Silalahi, A. (2021). Implementation of an Inquiry Learning Model with Science Literacy to Improve Student Critical Thinking Skills. International Journal of Instruction, 14(2), 117-138. https://doi.org/10.29333/iji.2021.1428a

Tanti, Maison, Mukminin, A., Syahrial, Habibi, A., \& Syamsurizal. (2018). Exploring the relationship between preservice science teachers beliefs and self-regulated strategies of studying physics: A structural equation model. Journal of Turkish Science Education, 15(4), 79-92. https://doi.org/10.12973/tused.10247a

Wang, J., Guo, D., \& Jou, M. (2015). A study on the effects of model-based inquiry pedagogy on students' inquiry skills in a virtual physics lab. Computers in Human Behavior, 49, 658-669. https://doi.org/10.1016/j.chb.2015.01.043

Wartono, W., Alfroni, Y. F., Batlolona, J. R., \& Mahapoonyanont, N. (2019). Inquiryscaffolding learning model: Its Effect on critical thinking skills and conceptual understanding. Jurnal Ilmiah Pendidikan Fisika Al-Biruni, 8(2), 245-255. https://doi.org/10.24042/jipfalbiruni.v8i2.4214

Xie, T., Zhang, F., \& Wu, E. (2017). Perceived effectiveness of science inquiry in the 3D virtual world. EURASIA Journal of Mathematics, Science and Technology Education, 13(8). https://doi.org/10.12973/eurasia.2017.01036a

Yakar, Z., \& Baykara, H. (2014). Inquiry-based laboratory practices in a science teacher training program. Eurasia Journal of Mathematics, Science and Technology Education, 10(2), 173-183. https://doi.org/10.12973/eurasia.2014.1058a

Yuliati, L., Riantoni, C., \& Mufti, N. (2018). Problem solving skills on direct current electricity through inquiry-based learning with PhET simulations. International Journal of Instruction, 11(4), 123-138. https://doi.org/10.12973/iji.2018.1149a 